\title{
O patriarcalismo possível: relações de poder em uma região do Brasil escravista em que o trabalho familiar era a norma*
}

\author{
Cacilda Machado*
}

\begin{abstract}
Esse artigo procura reunir indicadores da existência de uma peculiar forma de patriarcalismo em regiões de agricultura de alimentos do Brasil escravista, nas quais a população cativa era pouco relevante, do ponto de vista demográfico, e onde o trabalho familiar era a norma. O locus de estudo é a Freguesia de São José dos Pinhais (PR), na passagem do século XVIII para o XIX, cuja dinâmica das relações sociais é analisada a partir de dados sobre composição dos domicílios, produção e posse de terras.
\end{abstract}

Palavras-chave: Patriarcalismo. Dependência. Escravidão.

\section{Introdução}

Em seu artigo polêmico, Mariza Corrêa (1994, p.15-42) $)^{1}$ resumiu as mais contundentes críticas ao conceito de "família patriarcal" produzidas pela historiografia brasileira. A autora enfatiza o exagero de se imputar a todas as áreas e grupos da sociedade colonial brasileira, bem como a todas as épocas, a hegemonia de um modelo mais apropriado para definir a prática de um grupo restrito da elite colonial - o de senhores de engenho de açúcar de Pernambuco.

Corrêa traça um quadro da diversidade econômica e social do largo território que constituía os domínios portugueses na América, entre os séculos XVI e XIX - realidade que não poderia ser acomodada nos estreitos limites do engenho ou da fazenda. Para ela, Gilberto Freyre e Antonio Cândido recuaram para o interior da instituição dominante num certo momento do Brasil colonial e, assumindo o olhar dos senhores brancos e suas famílias, negaram a possibilidade de autonomia aos demais grupos da sociedade nascente. Segundo a autora, a família patriarcal pode ter existido e seu papel ter sido extremamente importante, "apenas não existiu sozinha, nem comandou do alto da varanda da casa grande o processo total de formação da sociedade brasileira". Melhor seria aceitar que ela foi, de fato, um instrumento disciplinador (CORRÊA, 1994, p.24-34).

Nessas críticas, Marisa Corrêa baseouse especialmente em dados produzidos por estudos sobre população e família, a partir da década de 70 , os quais destacaram a existência, de acordo com as regiões econômicas e a condição social das populações, de múltiplas formas de composição domiciliar, de um grande número de domicílios nucleares e de mulheres chefiando

\footnotetext{
"Este artigo é uma versão resumida de um capítulo de tese de doutoramento, defendida em abril de 2006, no Programa de Pósgraduação em História Social da UFRJ.

${ }^{*}$ Historiadora. Professora do DEHIS/UFPR, lotada na ESS/UFRJ.

${ }^{1} \mathrm{O}$ trabalho foi publicado antes nos Cadernos de Pesquisa da Fundação Carlos Chagas, de maio de 1981.
} 
famílias. ${ }^{2}$ Questionando a validade dessas evidências, no entanto, já se argumentou que,

\begin{abstract}
se as famílias coloniais eram mais ou menos extensas, [...] eis um dilema de pouca relevância nos trabalhos de Freyre e Cândido. $E$ quer-nos parecer, ainda, que a maior ou menor concentração de indivíduos, fosse em solares, fosse em casebres, em nada ofuscava o patriarcalismo dominante, a menos que se pretenda que, pelo simples fato de não habitarem a casa-grande, as assim chamadas "famílias alternativas" viviam alheias ao poder e aos valores patriarcais, o que ninguém seria capaz de afirmar, seguramente (VAINFAS, 1989, p.110).
\end{abstract}

De todo modo, nos anos 80 e 90, inúmeros historiadores destacaram a vigência, no passado brasileiro, de modalidades de relações consensuais entre iguais, conhecidas e aceitas pela comunidade, pelos parentes e por autoridades civis e eclesiásticas, que estariam na origem da constituição de outras formas de família que não aquela de nítidos traços patriarcais. ${ }^{3}$

Eni Samara (1998, p.8) sintetizou toda a polêmica, ao indicar que os pesquisadores em geral se dividem em dois grandes "modos de ver": Dain Borges e Angela Mendes de Almeida, por exemplo, entendem a ordem patriarcal como um grande modelo "ideológico" e paradigmático de família; outros, como Muriel Nazzari, Alida Metcalf e Darrel Levi, ressaltam suas ambigüidades nos diversos contextos regionais, suas transformações ao longo do tempo e seus limites quando a raça e a classe são colocadas em questão.

Mesmo em trabalhos mais recentes o tema persiste, numa evidência do quanto as formulações de Freyre marcaram fundo a historiografia nacional. Silvia Maria Brügger (2002, cap. 1), por exemplo, a partir da noção de patriarcalismo como um conjunto de valores e práticas que colocam a família no centro da ação social, reitera sua presença em Minas ou em qualquer outra parte da Colônia ou do Império.

No presente artigo, procura-se discutir mais esse tema, partindo-se do princípio de que a apropriação do patriarcalismo de Freyre apenas como um conjunto de valores e práticas que colocam a família no centro da ação social, ou como um ideal disciplinador, presente nos diversos ambientes escravistas do Brasil ao longo de toda a sua história, não é útil para a ampliação do conhecimento. Apreendido de uma ou de outra maneira, o patriarcalismo pode tornarse um conceito genérico de dominação que pouco ou nada esclarece acerca de contextos específicos.

O patriarcalismo de Gilberto Freyre, concebido a partir do estudo dos engenhos de Pernambuco, tem grande força teórica porque sintetiza a arquitetura do poder gestado no conjunto das relações que ligavam os principais chefes da elite econômica aos seus familiares, aos seus (muitos) escravos, e à população de livres pobres que habitavam seus domínios e o entorno. Isso não significa afirmar a ausência de diferenças no interior da família senhorial, da escravaria e do grupo de livres pobres. Afinal, uma das características fundamentais de sociedades com traços de Antigo Regime é que nelas a mobilidade social não se resume a passagem de um estamento a outro. A ascensão social ocorre, em geral, no interior dos grupos (FERREIRA, 2005, p.6869). Sobretudo quando se trata de locus sociais aparentemente pouco hierarquizados, não se podem deixar de lado essas (outras) relações de poder.

Ao longo deste texto, procurou-se recuperar ao menos parte das redes de poder que organizavam hierarquicamente homens e mulheres livres na freguesia de São José dos Pinhais (PR), que, na passagem do século XVIII para o XIX, era uma região de agricultura de subsistência e de abastecimento, onde a população cativa era pouco relevante, do ponto de vista demográfico, e mesmo a elite tinha dificuldades em incorporar terras, escravos e dependentes aos seus domínios. Sugere-se, aqui, que a noção de "família patriarcal", tal como aparece em Casa-Grande \& Senzala e em

\footnotetext{
${ }^{2}$ Alguns exemplos dessa bibliografia: COSTA (1979), KUSNESOF (1980), SAMARA (1984).

${ }^{3}$ Por exemplo: Silva (1984), Figueiredo (1997), Londoño (1999).
} 
outros clássicos da nossa historiografia, não se constitui como o melhor modelo de análise desse locus social, embora nele as relações de poder também apresentavam uma conformação patriarcalista.

A análise foi realizada a partir do cruzamento de dados sobre composição domiciliar, produção e posse de terras, presentes nas Listas Nominativas de Habitantes - censos realizados regularmente na Capitania de São Paulo na passagem do século XVIII para o XIX - e no Inventário de Bens Rústicos - levantamento das propriedades rurais da mesma capitania, produzido em 1818. No processo de elaboração, foi particularmente útil o princípio formulado por Fredrick Barth (2000, p.128-130), de que as estruturas mais significativas da cultura - ou seja, aquelas que mais conseqüências sistemáticas têm para os atos e relações das pessoas - talvez não estejam em suas formas, mas sim em sua distribuição e padrões de não-compartilhamento.

\section{A freguesia de São José dos Pinhais}

O vilarejo de São José dos Pinhais fazia parte da porção meridional da Capitania de São Paulo, território que mais tarde formou o Paraná. Esta região começou a ser explorada pelos portugueses já no século $\mathrm{XVI}$, no entanto a ocupação foi mais efetiva somente a partir de 1570-1580, quando ali se encontrou ouro aluvional. Em 1617, no litoral, foi fundada a vila de Paranaguá, que se tornou em centro da então recém-criada Capitania de Nossa Senhora do Rosário de Paranaguá. A partir do início do século XVIII, o ouro das Minas Gerais eclipsou a modesta produção local e, em 1711, a região passou à condição de comarca da Capitania de São Paulo. Muito antes da decadência aurífera, porém, os mineradores avançaram pela Serra do Mar até o planalto, onde fundaram novos núcleos populacionais, como os de Nossa Senhora da Luz dos Pinhais (Curitiba) e de São José dos Pinhais (na região contígua a Curitiba), povoações iniciadas ainda no século XVII.

À medida que se exauria o ouro, os habitantes do planalto voltaram-se para a agricultura, a pecuária e o tropeirismo. Estas duas últimas atividades rapidamente se vincularam à economia do Centro-Sul, em face da grande demanda por alimentos em Minas Gerais. No século XVIII, o alto preço do gado nas Minas contribuiu para a multiplicação das fazendas de criação e de invernagem, a maioria delas nos Campos Gerais, especialmente após 1730 , quando foi aberto o Caminho do Viamão, que ligava o Continente do Sul a Sorocaba, passando necessariamente pelo Paraná. Graças a essas atividades, incrementou-se a ocupação do planalto paranaense, em direção ao oeste, e Curitiba desenvolveu-se como centro importante, disputando com Paranaguá a hegemonia econômica e política local, até se tornar sede da Comarca, em 1812.

Simultaneamente à criação e à invernagem, a população do planalto, especialmente aquela estabelecida em Curitiba e seu entorno (inclusive São José dos Pinhais), produzia milho, trigo, feijão e mandioca, atividade que garantia o abastecimento regional e dava suporte ao setor de exportação. Nessa região, as propriedades eram em geral menores do que as dos Campos Gerais, compondo-se sua paisagem agrária principalmente de sítios agrícolas e, de quando em quando, uma fazenda. Ali a população de escravos e agregados era menos numerosa, se comparada à presente nos Campos Gerais, e o trabalho familiar adquiria maior peso.

\section{A produção de dependentes}

No período analisado, a população livre de São José dos Pinhais, e de boa parte da região do Paraná, caracterizava-se pelo expressivo contingente de não-brancos. De acordo com os dados dos mapas populacionais, para seis anos entre 1798 e 1830, era tímida a presença de negros na população livre da freguesia (até 1,5\%), porém, a proporção daqueles identificados como pardos variou entre $22 \%$ e $49,5 \%$ (COSTA e GUTIÉRREZ, 1985, passim).

Do conjunto dos livres, eram poucos os que podiam ter escravos: em 1782, 80,6\% dos 160 domicílios do vilarejo não eram escravistas; em 1803 estes constituíam 
$79,9 \%$ das 319 unidades domiciliares, chegando em 1827 a $83,6 \%$ (de 587 domicílios). Do seleto grupo de escravistas, $58 \%$ tinham apenas de um a quatro cativos em 1782; em 1803 esse grupo chefiava $66 \%$ dos domicílios com escravos, aumentando para $75 \%$ em 1827 . A participação das escravarias médias - cinco a nove cativos - diminuiu sensivelmente no período (de $29 \%$ para $27,4 \%$ e depois para $24 \%$ ), e reduziu-se mais ainda a de grandes escravarias (mais de dez) - de 12,9\% para $6,5 \%$ e finalmente para apenas $1 \%$ (Tabela 1). Conforme já se anotou, Curitiba e principalmente São José dos Pinhais foram os casos mais extremos da representatividade do pequeno plantel escravista no Paraná no século XIX (PENA,1999, p.30).

Como em outras partes do Brasil Meridional, alguns domicílios de São José dos Pinhais tinham agregados entre os seus membros. Este específico grupo social há muito vem sendo observado pela historiografia. Oliveira Vianna, por exemplo, escreveu que as três classes fundamentais das regiões rurais do Centro-Sul eram a família senhorial, os agregados e os escravos. Sobre os agregados este autor sublinhou que constituíam uma sorte de colonos livres.

Habitam fora dos perímetros das senzalas, em pequenos lotes, em toscas choupanas, circundantes ao casario senhorial, que do alto da sua colina, os centraliza e domina. [...] Essa é a origem da classe dos agregados ou moradores do domínio. Ela é o refúgio a que se ocolhem os peninsulares, de estração plebéia, sem meios para requererem sesmarias, lançados na agitação colonial e postos defronte da escravaria dos grandes domínios. [...] Porém, logo essa plebe entra a receber o transbordo das senzalas repletas, as récovas da escravaria, o sobejo da mestiçagem das fazendas. [...] O elemento branco acaba afundando-se nessa ralé absorvente que, um pouco mais tarde, se fará o peso específico da população dos moradores (OLIVEIRA VIANNA, 1987, p.65-67).

Embora o autor acabe por considerar indivíduos de condição muito variada numa mesma categoria (agregados), o fato é que na caracterização acima, e para além de seu conteúdo elitista, Oliveira Vianna anuncia uma disposição em pensar aquela sociedade rural de modo a incluir a imensa faixa de sua população que não era escrava nem escravista.

Muito tempo depois, em um trabalho voltado exclusivamente para o tema, Eni Samara (1997, p.42) procurou definir melhor a categoria "agregado". A partir de pesquisa sobre a vila de Itu, na passagem do século XVIII para o XIX, a autora afirma tratar-se de uma sorte de homens, mulheres e crianças que tinham em comum o fato de não possuírem terras ou casa própria, tendo, portanto, que se ajustar aos

TABELA 1

Domicílios, segundo número de escravos existentes São José dos Pinhais - 1782-1827

\begin{tabular}{|c|c|c|c|c|c|c|}
\hline \multirow{2}{*}{$\begin{array}{c}\text { Número } \\
\text { de } \\
\text { escravos }\end{array}$} & \multicolumn{2}{|c|}{1782} & \multicolumn{2}{|c|}{1803} & \multicolumn{2}{|c|}{1827} \\
\hline & $\begin{array}{c}\text { № de } \\
\text { domicílios }\end{array}$ & $\%$ & $\begin{array}{c}\text { № de } \\
\text { domicílios }\end{array}$ & $\%$ & $\begin{array}{c}\text { № de } \\
\text { domicílios }\end{array}$ & $\%$ \\
\hline 1 & 4 & 12,9 & 17 & 27,4 & 37 & 38,5 \\
\hline 2 & 7 & 22,6 & 10 & 16,1 & 18 & 18,8 \\
\hline 3 & 3 & 9,7 & 11 & 17,8 & 11 & 11,5 \\
\hline 4 & 4 & 12,9 & 3 & 4,8 & 6 & 6,2 \\
\hline Subtotal 1 & 18 & 58,1 & 41 & 66,1 & 72 & 75,0 \\
\hline 5 a 9 & 9 & 29,0 & 17 & 27,4 & 23 & 24,0 \\
\hline 10 a 19 & 4 & 12,9 & 4 & 6,5 & 1 & 1,0 \\
\hline Subtotal 2 & 13 & 41,9 & 21 & 33,9 & 24 & 25,0 \\
\hline Total geral & 31 & 100,0 & 62 & 100,0 & 96 & 100,0 \\
\hline
\end{tabular}

Fonte: Listas nominativas de S.José dos Pinhais de 1782, 1803 e 1827.

Cópias: Cedope/DEHIS-UFPR.

Originais: Arquivo do Estado de São Paulo. 
proprietários das áreas rurais ou urbanas, dentro dos mais diferentes tipos de relações.

Por seu lado, Carlos Bacellar enfatiza que a agregação era sintoma de uma sociedade em que alguns segmentos, por diversas razões, não encontravam condições de se estabelecer autonomamente. Buscava-se, assim, trocar trabalho por teto e comida, ou instalar-se "de favor" em terras de outrem. Muitos agregados eram indivíduos solitários e extremamente pobres e desenraizados, mas também podiam ser chefes de família que detinham, inclusive, a posse de um ou dois escravos. Também variava o status do agregado no interior de um domicílio ou de uma propriedade: ele podia ser um idoso, um inválido ou uma mulher sozinha com filhos pequenos, podia ser um ex-escravo com parentes no plantel do chefe do fogo, ou mesmo um migrante recém-chegado à espera de oportunidade de ascensão social. Mas também podia ser o filho recém-casado, o irmão ou o pai do chefe do domicílio (BACELLAR, 2001).

Nas listas nominativas de São José dos Pinhais, aparecem três categorias de indivíduos livres agregados a alguns dos domicílios: parentes não nucleares, expostos e pessoas sem vínculos de parentesco com o chefe do fogo (estes, os que mais sistematicamente são identificados, nas listas nominativas de São José, pelo termo agregado e, portanto, assim serão referenciados daqui por diante).

Em 1782, cerca de 4\% dos 848 livres que viviam em São José dos Pinhais estavam agregados em domićlio alheio; eles eram pouco mais de $5 \%$ das 1.689 pessoas livres, em 1803, e 3,7\% (dos 2.795 livres), em 1827. Sobre expostos e parentes, não se dispõe de dados para 1782, pois nesse ano as informações da lista de habitantes apresentam muitas lacunas quanto a estes quesitos. Ainda assim, sabe-se que pelo menos $10 \%$ da população livre da freguesia vivia sob uma destas condições em 1803 e $4,2 \%$ em 1827. Nesse último ano, os números podiam ser ainda maiores, uma vez que os dados são menos precisos do que os da lista de 1803. Entretanto, considerando-se os índices obtidos, a população livre formada por agregados, parentes e expostos correspondia a 15\% em 1803 e a $8 \%$ em 1827, lembrando que são anos em que a participação da população cativa era de $13 \%$ e de $9,2 \%$, respectivamente.

Não eram poucos os domicílios com agregados, parentes e/ou expostos em São José dos Pinhais. Eles tinham presença marcante, especialmente em 1803. Dos 160 fogos da freguesia, $10 \%$ tinham agregados em 1782; nada menos que 18,5\% dos 319 domicílios registrados em 1803 e cerca de $12 \%$ das 587 unidades recenseadas em 1827. Em 1803, 23,2\% dos domicílios tinham pelo menos um parente não-nuclear ou um exposto, sendo este índice de 9,7\% em 1827. No entanto, não é provável que eles estivessem presentes em menor número, ao menos não tanto, em 1827. Tudo indica ser este mais um caso de sub-registro. No conjunto dos domicílios do vilarejo, cerca de $30 \%$ tinham ao menos um membro que não pertencia à família nuclear em 1782. Esse índice era de 62\% em 1803 (lembrando que esta é a Lista com informações mais precisas) e de $38 \%$ em 1827 (Tabela 2).

TABELA 2

Domicílios, segundo sua composição

São José dos Pinhais - 1782-1827

\begin{tabular}{lccc} 
& & \multicolumn{2}{c}{ Em porcentagem } \\
\hline Composição domiciliar & $\mathbf{1 7 8 2}$ & $\mathbf{1 8 0 3}$ & $\mathbf{1 8 2 7}$ \\
\hline Família + escravos & 19,4 & 20,1 & 16,4 \\
Família + agregados & 10,0 & 18,5 & 12,0 \\
Família + parentes e/ou expostos & 0,0 & 23,2 & 9,7 \\
Família + escravos e/ou agregados e/ou parentes e expostos & 29,4 & 61,8 & 38,1 \\
\hline
\end{tabular}

Fonte: Listas nominativas de S.José dos Pinhais de 1782, 1803 e 1827.

Cópias: Cedope/DEHIS-UFPR.

Originais: Arquivo do Estado de São Paulo. 
Em São José, o grupo formado pelos agregados era marcadamente feminino: nos três anos observados $2 / 3$ dele eram compostos por mulheres, enquanto na população livre não-agregada elas representavam a metade. $\mathrm{O}$ grupo também era mais jovem: a idade média dos agregados era de 22,6 anos em 1782, 19,7 anos em 1803 e 17 anos em 1827. Já para os livres não-agregados, a idade média era, nos respectivos anos, de 24,2, 20,8 e 19,6 anos. Contudo, em relação à população livre nãoagregada, apenas em 1782 havia uma proporção maior de crianças entre os agregados. A principal característica desse grupo era a pequena proporção de idosos (especialmente em 1803).

Este quadro não difere muito do encontrado em Itu, por Eni Samara, e a autora afirma que o mesmo era regra geral na Capitania de São Paulo. No conjunto dos recenseamentos paulistas iniciados na segunda metade do século XVIII, era grande o número de mulheres solteiras e viúvas, muitas vezes com filhos, que se agregavam às famílias locais. No entanto, apesar da relativa freqüência com que aparecem crianças agregadas nos fogos, eram mais numerosos os agregados adultos (SAMARA, 1977, p.55-60).

Em São José dos Pinhais, a maior parte dos fogos com agregados abrigava apenas um ou dois deles, e em nenhum fogo havia mais do que sete. Embora existissem agregados em domicílios escravistas, esta situação era mais comum naqueles sem cativos (que constituíam $75 \%$ dos fogos com agregados em 1782, quase $70 \%$ em 1803 e $64 \%$ em 1827), e a maior parte dos agregados encontrava-se neste tipo de domicílio (85\% em 1782, 63\% em 1803 e $61 \%$ em 1827).

No entanto, por esses mesmos dados também se infere que, conforme se reduzia o contingente cativo na freguesia, mais os escravistas incorporavam agregados. Em outras palavras, a possibilidade de homens e mulheres pobres de atrair agregados provavelmente se reduzia quando os escravistas (homens e mulheres de maior poder econômico e político no interior do vilarejo) passavam a se interessar mais por aquela mão-de-obra, devido à dificuldade em adquirir cativos.

Os dados referentes a Itu, estudados por Eni Samara, tendem a reforçar a hipótese. Como já indicado, a autora observou esta vila no momento de expansão da economia açucareira. Ela percebeu que a larga penetração de mão-de-obra escrava relegava a segundo plano a mão-de-obra livre nas grandes fazendas, e que os agregados concentravam-se mais nas propriedades de lavoura de mantimentos e nas unidades domiciliares da vila. Em 1798, em um bairro onde se localizavam grandes propriedades canavieiras, a pesquisadora não computou nenhum agregado e os escravos representavam $83 \%$ dos moradores, enquanto na rua do Ouvidor, no mesmo ano, $32 \%$ dos moradores eram agregados e menos de $11 \%$ escravos. Os índices levantados para os demais bairros e ruas de ltu seguem praticamente o mesmo padrão. Por esta razão, Samara depreende que os agregados eram utilizados como mão-deobra, nas áreas de lavoura comercial, somente em períodos de carência de escravos. Além disso, quanto mais crescia a população cativa na região, mais se reduzia a de agregados: entre 1785 e 1829 , a proporção de escravos aumentou paulatinamente de $25 \%$ até $55 \%$, enquanto a dos agregados, que no início do período correspondia a cerca de $10 \%$ da população, passou para apenas 4\% em 1829 (SAMARA, 1977, p.43-47 e 73-74).

Também as informações reunidas por Roberto Guedes Ferreira reforçam a assertiva apresentada neste artigo. A vila de Porto Feliz, vizinha a Itu, no século XIX viu crescer significativamente sua população cativa, devido à expansão da economia canavieira. Entre 1798 e 1818, os escravos representavam entre $31 \%$ e $36 \%$ da população total do lugar. Desde então, este porcentual subiu para $40 \%$ em 1820 e $45 \%$ em 1824 , chegando a $51 \%$ em 1829 . Em movimento inverso, a proporção de agregados na população total, que girava em torno de $11 \%$ entre 1798 e 1820 , decresceu para $9,5 \%$, em 1824, e para apenas 5\%, em 1829. Além disso, $36,5 \%$ dos fogos registrados em 1820 tinham agregados, diminuindo para 
$30,6 \%$ em 1824 e para $19 \%$ em 1829 . Finalmente, em 1818, os domicílios escravistas que também agregavam livres representavam $12,5 \%$ do total de fogos da vila e $38,5 \%$ dos fogos escravistas, passando para $8 \%$ e $26 \%$, respectivamente, em 1829. Do mesmo modo, $48,5 \%$ dos agregados de Porto Feliz estavam em fogos escravistas em 1798, índice que caiu para $45 \%$ em $1829 .{ }^{4}$

Para o agregado, estabelecer-se em domicílio alheio podia funcionar como estratégia de sobrevivência. Em estudo sobre a Lapa, Maria Luiza Andreazza (2002, p.1011) observa que muitas mulheres, especialmente as mães-solteiras, por certa fase da criação dos filhos, agregavam-se a um domicílio, à espera de condições para alçar autonomia. Em São José dos Pinhais isso também não deveria ser incomum, pois, como se viu, era grande o número de muIheres, crianças e jovens nesse grupo. Uma outra razão foi apontada por Bert Barickman (2003, p.167-209), que estudou os plantadores de mandioca do Recôncavo baiano, quando sugere que, apesar de a região contar com uma fronteira aberta, nem todos os homens pobres se interessavam em desbravar novas terras, preferindo permanecer agregados de algum engenho, onde teriam acesso mais fácil ao mercado para vender sua produção excedente. Com estes exemplos, pretende-se salientar, enfim, que a perda da autonomia era o preço a pagar pela possibilidade de viver da melhor maneira possível, até conseguir alçar a uma melhor condição. Ainda que nem sempre isso acontecesse, talvez muitos agregados acreditassem que tais expectativas poderiam ser mais facilmente concretizadas sob a proteção de homens mais poderosos.

A esse respeito, Eni Samara (1977, p.69-71) indica o potencial conflito que mediava tal relação de dependência, ao sugerir que a falta de serviço na fazenda e a abertura de novas áreas para o plantio ou mesmo novas possibilidades de trabalho na vila de Itu, nos séculos XVIII e XIX, pode ser uma das explicações para a insta-bilidade residencial dos agregados: "num ano estão num domicílio, no outro já não se encontram mais lá". Dessas palavras, pode-se deduzir que, se em algumas situações reafirmar a submissão podia ser boa estratégia, em outras, sair de uma relação de dependência para outra era mais eficaz.

Como já mencionado anteriormente, além dos agregados, uma parcela dos membros de alguns domicílios de São José dos Pinhais era formada por parentes nãonucleares, ou por expostos. Esta última categoria era comumente encontrada nas inúmeras vilas e freguesias do Brasil, na época. A condição dos expostos era, em geral, bastante dúbia, ora inseridos nos domicílios como se filhos fossem, ora distinguidos por sua específica condição, ora tratados como agregados. A própria forma como foram recenseados em São José dos Pinhais dá uma dimensão dessa dubiedade, pois aparecem expostos apenas em 1803, e certamente eles existiam em 1782 e em 1827, já que a exposição era comum no vilarejo, ${ }^{5}$ mas provavelmente foram contabilizados como filhos ou como agregados. Em 1803 foi indicada a presença de 41 expostos em São José dos Pinhais (21 homens e 20 mulheres), crianças e jovens quase todos.

Os parentes não-nucleares presentes nos fogos da freguesia de São José dos Pinhais, no período, eram predominantemente mulheres e crianças. Nos dois anos aqui observados, as mulheres eram em geral irmãs, mas também mães, tias, sogras, noras e cunhadas; as crianças eram sobrinhos e principalmente netos (a prole, sobretudo, das filhas solteiras ou viúvas vivendo com os pais).

Tomando apenas o ano de 1803, observou-se que $13 \%$ (42 de 319 ) das unidades domiciliares possuíam dez ou mais membros. Destas, em sete (16,3\%)

\footnotetext{
${ }^{4}$ Esses dados foram generosamente cedidos por Roberto Guedes Ferreira, retirados de um banco de dados por ele criado para a confecção de sua tese de doutoramento (FERREIRA, 2005).

${ }^{5} \mathrm{Em} 30$ anos (de 1775 a 1804), foram batizadas 1.965 crianças em São José dos Pinhais, sendo que 206 (10,5\%) eram expostas (Livros 1 e 2 de batismos), dando uma média de 6 a 7 batismos de expostos por ano.
} 


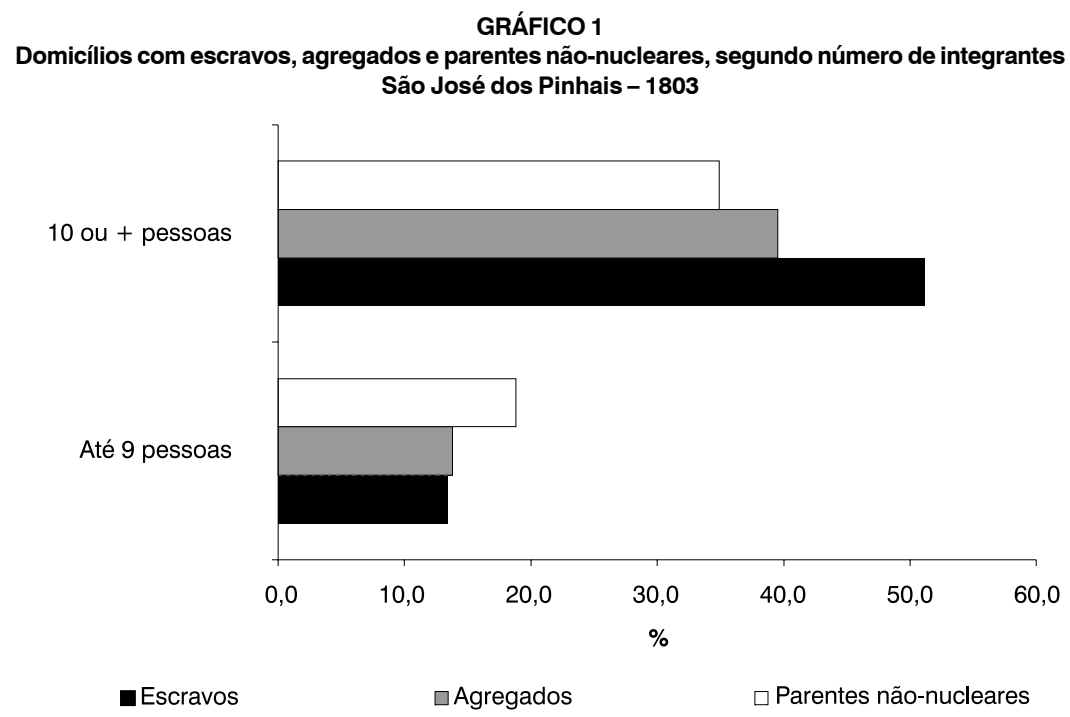

Fonte: Lista nominativa de São José dos Pinhais de 1803. Cópia: Cedope/DEHIS-UFPR.

Original: Arquivo do Estado de São Paulo.

viviam apenas famílias nucleares, e as demais adotavam estratégias de compo-sição mista. Desse conjunto, além dos parentes nucleares, em 22 dos fogos havia escravos, 17 abrigavam agregados e 15 tinham parentes não-nucleares ou expos-tos. No mesmo ano, dos 277 fogos com até nove membros, 168 (61\%) eram nucleares (ou de solitários) e os demais apresentavam composições mistas, sendo que em 52 existiam parentes ou expostos, 38 abrigavam agregados e em 37 havia escravos. ${ }^{6}$

Tudo indica que as unidades com número menor de pessoas tinham esta característica exatamente porque suas chefias não conseguiam atrair muitos dependentes. $\mathrm{E}$ esta dificuldade era mais real em relação a escravos, um pouco menos no que se refere a agregados e menor ainda quanto a parentes. Já as unidades mais extensas garantiam esta característica preferencialmente com escravos, mas também com agregados e, em menor grau, com parentes não-nucleares (Gráfico 1).

Quadro semelhante foi encontrado em Paranaguá. Dos 99 fogos que, em 1803, tinham dez ou mais integrantes, apenas 18 $(18,2 \%)$ eram formados somente pela família nuclear; dos 888 fogos com menos de dez integrantes, 585 (65,9\%) tinham esta conformação. Dos domicílios com menos de dez membros, em 19\% havia parentes nãonucleares, 15,5\% abrigavam agregados e $13,4 \%$ tinham escravos. Dos domicílios com dez ou mais membros, $78,8 \%$ possuíam escravos, em $30,3 \%$ havia agregados e $17,2 \%$ abrigavam parentes não-nucleares. ${ }^{7}$ Portanto, nessa vila do litoral paranaense, onde no período a participação de cativos era maior do que em São José dos Pinhais, a preferência pela mão-de-obra cativa, por parte dos mais poderosos, era ainda mais evidente.

\footnotetext{
${ }^{6}$ No cálculo sobre a composição dos domicílios, foram incluídos os escravos, pois, como estão sendo abordadas as relações econômicas e políticas no interior dos fogos, os cativos não podem ser tratados separadamente. Isso porque tinham um papel econômico nas unidades domiciliares e, embora fossem propriedade de outrem, eles faziam parte da rede de dominação e dependência que garantia a reprodução da hierarquia social.

${ }^{7}$ Lista Nominativa de Habitantes de Paranaguá, 1803. Cópia do Cedope-UFPR, originais no Arquivo do Estado de São Paulo.
} 
GRÁFICO 2

Domicílios com escravos, agregados e parentes não-nucleares, segundo a idade do chefe do domicílio São José dos Pinhais - 1803

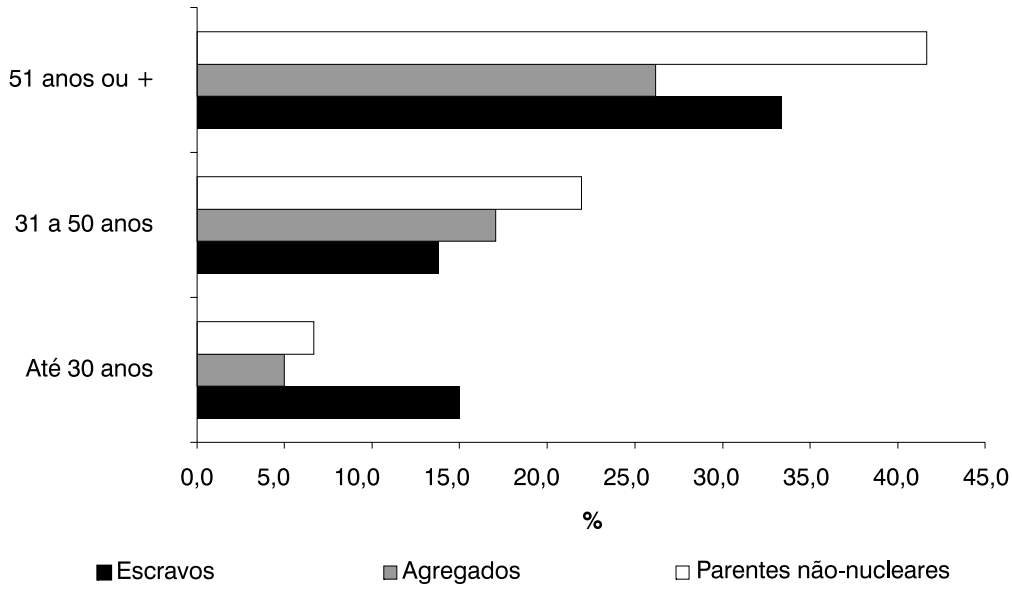

Fonte: Lista nominativa de São José dos Pinhais de 1803.

Acrescente-se que a capacidade de reunir pessoas no domicílio aumentava de acordo com a idade. Em São José dos Pinhais, ainda tomando como base o ano de 1803 , apenas $1,7 \%$ dos fogos com chefia de até 30 anos possuíam dez ou mais integrantes. Para os domicílios com chefias entre 31 e 50 anos, essa proporção correspondia a $11,4 \%$ do total e, para aqueles com chefes de 51 anos ou mais, era de $26,2 \%$. Ao longo do ciclo familiar mudavam também as condições de arregimentação de dependentes, pois nos primeiros anos da constituição de domicílio autônomo (chefes com até 30 anos) aparentemente havia maior dificuldade para atrair parentes não-nucleares e agregados (Gráfico 2).

Por fim, vale a pena pensar o acolhimento de expostos, parentes e, sobretudo, agregados, em São José dos Pinhais, no âmbito da discussão de uma prática costumeira na Europa dos séculos XVII e XVIII, qual seja, a circulação dos filhos, um fenômeno que ficou conhecido pela expressão life-cycle servant, cunhada por Peter Laslett (BURGUIÈRE, 1998, p.37).

Muitas vezes tal prática tinha finalidade pedagógica e, em algumas regiões, era freqüente mesmo entre os ricos, que trocavam de filhos para que adquirissem competência e conhecimentos. No entanto, os autores em geral concordam que o costume esteve mais disseminado em regiões e meios desfavorecidos, pois permitia aos camponeses pobres verem-se livres de uma parte do fardo familiar, ao mesmo tempo em que proporcionava a outras famílias um complemento de mão-de-obra, especialmente enquanto seus filhos eram de tenra idade (BURGUIÈRE, 1998, p.38).

É provável que tal quadro pudesse ser eventualmente encontrado em São José dos Pinhais, notadamente no caso de parentes. Porém, ainda que o vilarejo tivesse poucos escravos, é provável que ali a prática da agregação de não-parentes era menos um signo da existência de uma comunidade camponesa ${ }^{8}$ e mais um índice de diferenciação escravista. O principal argumento a reforçar tal afirmativa talvez seja a designação da cor das pessoas: $74 \%$ dos agregados foram identificados como pardos ou negros em 1803; índice que se ampliaria para $82 \%$ em 1827 . Ademais, dos 23 agregados brancos de São José em 1803, 22 estavam em fogos chefiados por

\footnotetext{
${ }^{8}$ Embora a prática da circulação de filhos, na Europa, muitas vezes também pressupunha um arranjo hierárquico.
} 
brancos e todos os 19 agregados brancos, em 1827, viviam em fogos com chefia branca. Já entre os 63 não-brancos que em 1803 eram agregados, apenas 24 residiam em fogos de não-brancos e, em 1827, apenas 26 dos 84 estavam estabelecidos em domicílios de chefia não-branca.

Por fim, observe-se que, embora os agregados mais comumente encontrados na freguesia fossem crianças e jovens, 0 perfil dos domicílios em que viviam difere muito do que geralmente se encontra em fontes européias. Apenas para citar alguns exemplos, esse era o caso de Angélica, uma parda de seis anos, que estava agregada no domicílio do lavrador José Martins de Brito, um branco de 49 anos, casado e com seis filhos entre 5 e 22 anos (domicílio 21, Lista de 1803). Ou ainda, dos jovens Sypriano (12 anos), Manoel (11 anos), Anna (dez anos), Francisca (nove anos) e Antonia (seis anos), todos pardos, agregados na casa de Camilio de Lima, fazendeiro branco, de 29 anos, casado, sem filhos e proprietário de 11 escravos (domicílio 189, Lista de 1803).

Também não era incomum a agregação de pardos e negros livres casados com escravos do domicílio. E ainda alguns agregados poderiam ter outros laços de parentesco com escravos dos domicílios além do nuclear -, os quais, no entanto, muito dificilmente podem ser recuperados pelo historiador.

Em alguns fogos talvez houvesse a agregação de forros, o que não é especificado de forma sistemática pelas listas de São José, entretanto, a historiografia tem acentuado a grande ocorrência de agregação de forros ou livres de cor, especialmente mulheres idosas ou jovens com seus filhos pequenos. De fato, essa situação foi encontrada nas treze indicações de agregados forros em listas nominativas de Paranaguá (nove em 1783 e quatro em 1830). Como enfatizou Manuela Cardoso da Cunha (1985, p.48-51), a "esperança da manumissão (...) passava pela dependência pessoal do senhor, ou eventualmente de outro senhor". Ainda conforme a autora, o que a "alforria revela é uma expectativa de transformar o escravo num cliente, agregado".

Os dados até aqui apresentados permitem inferências que transcendem a mera identificação de uma morfologia doméstica, uma vez que se referem a práticas sociais importantes, fornecendo subsídios que possibilitam avançar no entendimento do funcionamento de uma sociedade escravista, por certo, mas com poucos escravos.

A presença de agregados (principalmente), expostos e parentes nos domicílios de São José dos Pinhais (e de outras vilas e freguesias da Capitania de São Paulo) sugere a releitura das relações de poder em sociedades escravistas, pois indica a generalização de uma específica prática patriarcalista entre os livres. Nela, alguns eram mais bem-sucedidos - aqueles com maior poder econômico e político para tornar um estranho sua propriedade ou seu dependente -; os menos poderosos perseguiam o mesmo objetivo, embora raramente tivessem condições de exercer seu poder de mando para além da parentela. A análise dos dados sobre atividade econômica e posse de terras, no item a seguir, deve contribuir para a clarificação do que até aqui foi exposto.

\section{Atividades econômicas e propriedade das terras}

No período, como já mencionado, a população da freguesia de São José mantinha-se basicamente do fruto do trabaIho na agricultura e na criação, o que era característica de toda a região de Curitiba e seu entorno. Os dados sobre atividades econômicas, presentes nas listas nominativas, ajudam a completar esse quadro.

A lista de 1803 traz a ocupação do chefe do domicílio bem como suas exportações no ano. ${ }^{9}$ Considerando-se

\footnotetext{
${ }^{9} \mathrm{Na}$ lista consta o que o domicílio exportou, e não o que vendeu, portanto, pode-se deduzir que os dados referiam-se ao que o lavrador e/ou pecuarista vendeu fora do vilarejo.
} 
esses dois elementos (isto é, classificando como artesão e lavrador, por exemplo, um chefe de domicílio que se identificou como sapateiro e exportou farinha de trigo; ou como lavrador e pecuarista um chefe de domicílio que tenha declarado ser lavrador, mas também exportou toucinho e bois), foram obtidos os seguintes resultados: dos 319 chefes dos fogos, 291 (91\%) indicaram exercer algum tipo de atividade agrícola; destes, quase $70 \%$ declararam plantar apenas para o próprio sustento. Os demais, além de garantir a subsistência, conseguiram gerar excedentes para o mercado.

Da pecuária (criação de vacum) ocupavam-se pelo menos 25 chefes de fogos, cerca de $8 \%$ do total (em geral também lavradores), e quase todos declararam ter exportado parte da produção naquele ano, sendo que apenas dois homens foram identificados como proprietários de fazendas. Nesta lista foram ainda recenseados um minerador, três indivíduos ocupados na extração de erva-mate, dois tropeiros,$^{10}$ dois fazendeiros ${ }^{11}$ e 15 jornaleiros. Também se faz referência a ocupações mais ligadas ao meio urbano (artesãos, serviçais, eclesiásticos, militares, etc.), a nove chefes de domicílios que estariam no Sul (talvez conduzindo tropas ou negociando) e a cinco que viviam de esmolas.

A lista de 1827 é muito pobre em informações, pois nela consta apenas a ocupação. Por esta razão, para fins de comparação, preferiu-se utilizar os dados da lista de 1818, na qual, além da ocupação e da exportação, aparece a produção de cada domicílio. Nesse recenseamento, dos 494 chefes de fogos, 417 (84,4\%) dedica-vamse à lavoura e $146(29,5 \%)$ à pecuária. De todos eles, foi possível apurar que apenas sete correspondiam a proprietários de fazendas, 196 venderam parte de sua produção e 317 (56\%) produziram apenas para o seu próprio sustento. Entre os chefes de domicílio da freguesia, havia 26 apanhadores de erva-mate, dez fazendeiros e quatro capitães do mato. Também foram registrados alguns artesãos, eclesiásticos, profissionais liberais, etc., além de 24 pessoas identificadas como pobres ou mendigos. Ainda consta na lista que 12 indivíduos estavam "no Sul" e 13 "na guerrilha".

Em 1803, os domicílios que declararam vendas de produtos agrícolas tinham em média 1,3 cativo; para os que informaram plantar apenas para o próprio sustento essa média era de 0,5. Em 1818, quando o porcentual de escravos havia caído na freguesia, a desigualdade no interior desse grupo de lavradores se manifestava ainda mais claramente: as sete fazendas tinham em média seis cativos; os lavradores que declararam vendas possuíam em média um escravo (estas duas categorias, juntas, tinham em média 1,3 cativo); e os que produziram para o próprio sustento dispunham de apenas 0,1 cativo, também em média.

Todavia, a mão-de-obra da freguesia não se restringia aos escravos. Em 1803, aqueles que plantavam apenas para o sustento abrigavam em média 0,2 agregado e, para os que venderam parte de sua produção, essa média correspondia a 0,3. Em 1818, quando era menor a participação de escravos na freguesia, a diferença acentuou-se, com uma média 0,1 agregado para os que plantavam para o sustento e de 0,4 para os que venderam parte da produção (incluídos aí os grandes proprietários).

Parece que existia, de fato, uma relação diretamente proporcional entre volume da produção e número de pessoas integradas ao domicílio, pois, até mesmo no que se refere aos parentes (nucleares ou não) e aos expostos, os lavradores com produção excedente apresentavam, em média, um número maior de pessoas em seus domicílios: 5,7 em 1803 e 5,0 em 1818, contra 4,8 e 4,5 dos outros lavradores, nos respectivos anos.

Para o século XVIII, os dados sobre as formas de aquisição das terras no Paraná

\footnotetext{
${ }^{10} \mathrm{O}$ dado é impreciso, pois tropeiro é, normalmente, o comerciante de animais, enquanto condutor de tropas é aquele que leva os animais do comerciante até o ponto de revenda. Na lista não é possível saber se se trata de um ou outro.

${ }^{11}$ Fazendeiro era o administrador da fazenda, e não seu proprietário.
} 
estão esparsos e são imprecisos. Sabe-se que na região as sesmarias eram requeridas através da prática de alegar posse anterior. A ocupação pura e simples e a usurpação também eram formas muito comuns de obtenção de terras.

Para 1818, tem-se um quadro mais detalhado, graças à existência de um censo de terras realizado em toda a Capitania de São Paulo: o Inventário de Bens Rústicos. Horácio Gutiérrez, que estudou esse documento na parte relativa ao Paraná, aponta para a existência, em toda essa região, de grande número de pequenas propriedades, particularmente no litoral e nas áreas mais urbanizadas do planalto, voltadas basicamente para a agricultura de alimentos e o autoconsumo. No entanto, ressalta o autor, havia uma altíssima concentração da propriedade da terra no Paraná, pois, enquanto as propriedades com até 100 ha, perfazendo $64 \%$ do total, representavam apenas 1,6\% da área total, propriedades acima de 5.000 ha, correspondendo a 2,4\% do número total, apropriavam-se de $66,6 \%$ da área ocupada (GUTIÉRREZ, 2001, p.217).

Manipulando os dados do Inventário de Bens Rústicos de Curitiba (em que está incluído o registro das propriedades de São José dos Pinhais), foi possível confirmar e também detalhar tal quadro. Das 872 propriedades registradas em sete companhias de ordenanças,,$^{12} 524$ (60\%) tinham menos de 100ha, ocupando apenas 3,4\% das terras $(14.390,9$ ha de um total de $422.831,5 \mathrm{ha})$. Apenas 11 propriedades possuíam mais de 5.000 ha $(1,2 \%)$, no entanto ocupavam $32 \%$ do total de terras (135.641,0ha).

Especificamente para a região de São José dos Pinhais ( $3^{\mathrm{a}}$ e $7^{\mathrm{a}}$ companhias de ordenanças de Curitiba), encontrou-se 0 seguinte quadro: 115 propriedades com até 100ha compunham 56\% do total de 205 propriedades e ocupavam pouco menos de $4 \%$ da área total. Já as propriedades com mais de 4.000ha (não foram registradas propriedades com mais de $5.000 \mathrm{ha}$ ) eram apenas quatro (perfazendo cerca de $2 \%$ do total de propriedades), ocupando $70 \%$ da área total na freguesia.

É possível matizar esse quadro, em duas direções. Por um lado, porque na região não era incomum que uma só pessoa tivesse duas ou três propriedades não contíguas. Embora na freguesia de São José não tenham sido registradas propriedades com mais de 5.000ha, na manipulação dos dados identificou-se registro de pessoas com mais de uma propriedade. É o caso do Capitão Francisco da Costa, que possuía três propriedades, que, juntas, perfaziam um total 5.880,6ha. Além disso, não é improvável que alguns proprietários, especialmente os grandes, também possuíssem terras e escravos em outras freguesias do planalto e do litoral. Esta possibilidade parece ainda mais plausível quando se verifica que, em São José dos Pinhais, foram registradas oito propriedades cujos donos viviam em Santa Catarina, São Francisco, Paranaguá, Antonina ou Sorocaba.

Por outro lado, das 205 propriedades da freguesia de São José, 27 estavam em nome de escravos. Na verdade, não há como decifrar exatamente o que isso significa, pois a identificação é ambígua. Tem-se apenas a indicação de que, nessas terras, as pessoas estabelecidas eram "os escravos de fulano de tal". Como na lista nominativa do mesmo ano foram encontrados apenas quatro domicílios integrados somente por escravos, pode-se supor que aquelas terras eram ocupadas coletivamente por libertos e seus descendentes, ainda que não necessariamente fossem legalmente suas. Ocorre que, juntas, tais propriedades perfaziam o não desprezível índice de $22,4 \%$ da área total, chegando uma delas a medir pouco mais de 2.900ha. Talvez isso explique, ao menos parcialmente, a discrepância entre o número de propriedades e o de domicílios: foram registradas 215 propriedades na freguesia em 1818, no entanto, na lista nominativa do mesmo ano, foram recenseadas 494 uni-

\footnotetext{
${ }^{12}$ São, na verdade, 873 propriedades, porém, na $6^{a}$ companhia, uma propriedade foi registrada sem menção do seu tamanho, por isso não foi computada aqui.
} 
dades domiciliares. Logo, pode-se deduzir que muitos desses domicílios seriam ocupados por aqueles negros e pardos livres, embora certamente existissem inúmeras propriedades em nome de uma só pessoa, porém habitadas e cultivadas por sua família ampliada, organizada em domicílios nucleares, ou ainda por agregados que construíam casa na propriedade.

Feitas essas ressalvas, para avaliação das diferenças quanto às dimensões das propriedades arroladas no Inventário de Bens Rústicos de 1818, as medidas originais (em braças de fundos e testada) foram transformadas em alqueires paulistas, ${ }^{13}$ obtendo-se, assim, números "redondos". Os resultados desses cálculos estão resumidos na Tabela 3.

Verifica-se que, em relação a Curitiba, São José dos Pinhais apresentava menor concentração de terras, pois lá existiam, proporcionalmente, menos propriedades com até 50 alqueires, ocupando uma área maior de terras do que suas similares de Curitiba. Além disso, as propriedades médias, em São José dos Pinhais, ocupavam uma proporção muito mais significativa da área total das terras, do que aquelas similares nas demais companhias de ordenanças da região. Finalmente, em São José a elite latifundiária detinha uma porção muito menor das terras. Como já mencionado, era ainda maior a diferença entre São José e as localidades mais especializadas na pecuária e no tropeirismo, como Castro, onde os latifúndios monopolizavam boa parte das terras. Desse modo, a freguesia em estudo era exemplo extremo não apenas da representatividade do pequeno plantel de escravos na região, mas também seria a área do planalto em que as terras estavam menos concentradas.

Segundo o Inventário de Bens Rústicos, para o conjunto das sete companhias de ordenanças de Curitiba, $72 \%$ das propriedades (626) foram adquiridas por compra e/ou herdadas e $27 \%$ (237) eram posses. As demais eram sesmarias (5), ou um misto de herança e posse (2), sesmaria e herança (1), sesmaria e compra (1) e posse e compra (1). Exclusivamente para as companhias de São José dos Pinhais, as proporções foram de $76,8 \%$ para compra ou herança e de apenas $14 \%$ para posse.

TABELA 3

Propriedades e área ocupada, segundo tamanho das propriedades Curitiba e São José dos Pinhais - 1818

\begin{tabular}{|c|c|c|c|c|c|c|c|c|}
\hline \multirow{3}{*}{$\begin{array}{c}\text { Tamanho da } \\
\text { propriedade } \\
\text { (em alqueires } \\
\text { paulistas) }\end{array}$} & \multicolumn{4}{|c|}{$\begin{array}{l}\text { Número de } \\
\text { propriedades }\end{array}$} & \multicolumn{4}{|c|}{$\begin{array}{c}\text { Área ocupada } \\
\text { (em alqueire paulista) }\end{array}$} \\
\hline & \multicolumn{2}{|c|}{ Curitiba } & \multicolumn{2}{|c|}{ São José } & \multicolumn{2}{|c|}{ Curitiba } & \multicolumn{2}{|c|}{ São José } \\
\hline & N. Abs. & $\%$ & N. Abs. & $\%$ & N. Abs. & $\%$ & N. Abs. & $\%$ \\
\hline Até 50 & 435 & 65,3 & 124 & 60,5 & $5.648,2$ & 4,0 & $1.778,2$ & 4,9 \\
\hline De 50,1 a 100 & 53 & 7,9 & 22 & 10,7 & $3.910,6$ & 2,8 & $1.516,2$ & 4,1 \\
\hline Subtotal 1 & 488 & 73,2 & 146 & 71,2 & $9.558,8$ & 6,8 & $3.294,4$ & 9,0 \\
\hline De 100,1 a 300 & 86 & 12,9 & 20 & 9,8 & $17.018,5$ & 12,0 & $3.480,0$ & 9,5 \\
\hline De 300,1 a 500 & 42 & 6,3 & 20 & 9,8 & $18.038,1$ & 12,8 & $9.108,0$ & 24,9 \\
\hline De 500,1 a 1000 & 27 & 4,0 & 12 & 5,8 & $19.767,4$ & 14,0 & $9.172,0$ & 25,1 \\
\hline Subtotal 2 & 155 & 23,2 & 52 & 25,4 & $54.824,0$ & 38,7 & $21.760,0$ & 59,5 \\
\hline 1000,1 ou + & 24 & 3,6 & 7 & 3,4 & $77.058,5$ & 54,5 & $11.490,0$ & 31,5 \\
\hline Total & 667 & 100,0 & 205 & 100,0 & $141.441,3$ & 100,0 & $36.544,4$ & 100,0 \\
\hline
\end{tabular}

Fonte: Inventário de Bens Rústicos, 1818.

Cópia: Cedope/DEHIS-UFPR.

Original: Arquivo do Estado de São Paulo.

\footnotetext{
${ }^{13}$ Quando se tem, por exemplo, um terreno de $100 \times 500$ braças, é preciso calcular a área do terreno. Para isto, multiplica-se 500 $\times 2,20=1.100 \mathrm{~m} ; \mathrm{e} 100 \times 2,20=220 \mathrm{~m}$. A área do terreno é: $1.100 \mathrm{~m} \times 220 \mathrm{~m}=242.000$ metros quadrados. Para transformar em ha se deve dividir por 10.000, o que vai dar 24,2ha. Para calcular quantos alqueires paulistas existem em 24,2ha é só dividir por 2,42, o que dá 10 alqueires paulistas.
} 
Embora esse último porcentual seja pequeno, a posse era forma de ocupação relativamente usual para os mais pobres, pois $86 \%$ das propriedades obtidas por este meio, em São José, tinham até 50 alqueires. Dado que as terras do vilarejo eram de ocupação antiga (iniciada no século XVII, como se viu), esta característica pode indicar que alguns pecuaristas e invernistas que ali viviam, no passado, venderam ou abandonaram suas sesmarias, transferindo-se para a Lapa, Castro ou outras localidades dos Campos Gerais, mais próximas do Caminho do Viamão, e, assim, parte de suas terras tornou-se posse da população mais pobre.

O cruzamento dos dados do Inventário de Bens Rústicos de 1818 com as informações da lista nominativa de São José dos Pinhais, do mesmo ano, permitiu realizar outras inferências. Porém, como nem todas as pessoas relacionadas no inventário foram encontradas na lista nominativa e outras tinham homônimos, foram levantados os dados de apenas 90 proprietários, aqueles sobre os quais não se teve dúvida. Embora se trate de uma amostragem, ela é bastante significativa, já que se refere a 95 das 205 propriedades registradas (portanto $46 \%$ delas) e a cerca de $40 \%$ das terras ocupadas na freguesia. Além disso, abrange os diferentes estratos de proprietários: dos 90 selecionados, 66 possuíam terras com até 100 alqueires, 18 eram donos de 101 a 500 alqueires, três eram proprietários de 501 a 1.000 alqueires e três eram senhores de terras de com mais de 1.000 alqueires. Nos casos em que a pessoa tivesse mais de uma propriedade registrada em seu nome, foram somados os alqueires de todas, que passaram a ser tratadas como se fosse uma única.

$\mathrm{Na}$ busca de relação entre produtividade e tamanho da propriedade, inferiuse que a posse de poucas terras podia dificultar a produção de excedentes: dos 40 proprietários de até 50 alqueires sobre os quais havia informações a respeito da produção, 25 declararam ter plantado apenas para comer e outros 15 afirmaram ter feito alguma venda de lavoura e/ou criação naquele ano. Entre os proprietários com mais de 50 alqueires, apenas quatro declararam ter plantado só para o sustento e os demais (26) venderam gado e/ou produtos agrícolas naquele ano.

Parece que existia relação também entre tamanho da propriedade e número de pessoas no domicílio: dos 52 proprietários de até 50 alqueires de terras, 41

TABELA 4

Produção média dos domicílios, por tipo de cultura, segundo número de pessoas residentes São José dos Pinhais - 1818

\begin{tabular}{lcccc}
\hline Número de pessoas residentes & $\begin{array}{c}\text { Milho } \\
\text { (arrobas) }\end{array}$ & $\begin{array}{c}\text { Trigo } \\
\text { (arrobas) }\end{array}$ & $\begin{array}{c}\text { Feijão } \\
\text { (arrobas) }\end{array}$ & $\begin{array}{c}\text { Vacas } \\
\text { (unid.) }\end{array}$ \\
\hline Até 9 pessoas & 40 & 10 & 12 & 14 \\
10 pessoas ou mais & 76 & 32 & 15 & 29 \\
\hline
\end{tabular}

Fonte: Inventário de Bens Rústicos, 1818. Lista Nominativa de São José dos Pinhais, 1818.

Cópias: Cedope/DEHIS-UFPR

Originais: Arquivo do Estado de São Paulo.

TABELA 5

Produção média dos domicílios, por tipo de cultura, segundo dimensões das propriedades rurais São José dos Pinhais - 1818

\begin{tabular}{lcccc}
\hline $\begin{array}{c}\text { Dimensões das } \\
\text { propriedades (em alqueires) }\end{array}$ & $\begin{array}{c}\text { Milho } \\
\text { (arrobas) }\end{array}$ & $\begin{array}{c}\text { Trigo } \\
\text { (arrobas) }\end{array}$ & $\begin{array}{c}\text { Feijão } \\
\text { (arrobas) }\end{array}$ & $\begin{array}{c}\text { Vacas } \\
\text { (unid.) }\end{array}$ \\
\hline Até 50,0 & 39 & 20 & 12 & 14 \\
De 50,1 a 100,0 & 58 & 21 & 13 & 14 \\
Mais de 100,0 & 64 & 17 & 14 & 32 \\
\hline
\end{tabular}

Fonte: Inventário de Bens Rústicos, 1818 Lista Nominativa de São José dos Pinhais, 1818.

Cópias: Cedope/DEHIS-UFPR.

Originais: Arquivo do Estado de São Paulo. 
(79\%) não possuíam escravos, $33(63,5 \%)$ não abrigavam agregados e 44 (84,5\%) tinham no máximo dez pessoas morando em seu domicílio. Dos 36 proprietários de terras com mais de 50 alqueires, 17 (47\%) não possuíam escravos, 21 (58\%) não abrigavam agregados e 26 (72\%) viviam em domicílios com no máximo dez pessoas.

Também havia relação entre número de pessoas nas propriedades e produtividade. $\mathrm{Na}$ Tabela 4 observa-se que, para as quatro mais importantes produções da freguesia (milho, feijão, trigo e vacum), na amostragem os domicílios com dez ou mais pessoas tinham maior produção, em média, do que as propriedades de até nove pessoas.

Além disso, é possível que houvesse tendência à maior diversificação das atividades nas unidades domiciliares mais numerosas, pois, embora a moda fosse cinco atividades para os dois tipos de domicílios, no grupo daqueles com até nove pessoas existiam 13 unidades que desenvolviam apenas três ou quatro atividades; enquanto naquele com dez ou mais moradores nenhuma unidade apresentava menos de cinco atividades.

Finalmente, encontrou-se relação entre produtividade, diversificação das atividades e tamanho das propriedades: aquelas com até cinco atividades tinham em média 85 alqueires e as que desenvolviam entre seis e oito atividades possuíam uma média de 212 alqueires. Além disso, as produções de milho, feijão e vacum eram mais elevadas quanto maiores fossem as propriedades. Isso não era verdade apenas para o trigo, cultura de exportação cuja produção das propriedades médias e pequenas (nesta ordem) era maior, em média, do que a das propriedades grandes (Tabela 5).

Como mencionado anteriormente, os dados sobre composição dos domicílios estariam indicando a existência de uma prática "patriarcalista" na freguesia de São José, da qual todos participavam, visando a constituição, a manutenção ou a ampliação de suas redes de poder. O cruzamento dos dados sobre propriedade das terras e produção agrícola acrescenta novas variáveis a essa trama relacional, pois reunir dependentes em torno do fogo propiciava o incremento da produtividade e da produção de excedentes, possibilitando a atuação no mercado e, por sua vez, a incorporação de mais terras. E para grande parte das pessoas, somente com o correr do tempo isso se tornava possível.

\section{Relações de dependência em uma economia familiar}

A partir dos dados de São José dos Pinhais aqui apresentados, é possível resumir os aspectos que podem contribuir para o enriquecimento da discussão acerca do patriarcalismo no Brasil escravista. Para tanto, tome-se o trabalho de Maria Luiza Marcílio, Crescimento demográfico e evolução agrária paulista, 1700-1836, publicado em 2000, mas que se tornou "um clássico secreto", ${ }^{14}$ desde que foi apresentado como tese de livre-docência na Universidade de São Paulo, em 1974, e que ainda é uma das pesquisas mais abrangentes sobre a história paulista no período.

Para a discussão tratada no presente artigo, a referência a esta obra é especialmente pertinente, pois o vilarejo de São José dos Pinhais fazia parte da grande área socioeconômica estudada por Marcílio. Além disso, a configuração dos domicílios e a posse de escravos de São José dos Pinhais coincidem, no geral, com o quadro encontrado pela autora em grande parte das vilas e freguesias da região paulista.

Com base nas listas nominativas de habitantes das vilas e freguesias daquela capitania (incluindo o Paraná), Maria Luiza Marćlio afirma que eram minoria os fogos de grandes dimensões, posto que a média de pessoas livres girava em torno de 4,6 por fogo, e que, embora fosse crescente no período a entrada de escravos, em geral as escravarias eram diminutas. Em todas as regiões da capitania, com pequenas diferenças que não alteram o quadro total, havia a prevalência dos domicílios com

\footnotetext{
${ }^{14}$ Expressão cunhada por Stuart Schwartz no prefácio que escreveu para o livro (MARCíLIO, 2000, p.13).
} 
estrutura simples, inclusive entre os grandes proprietários: quase três quartos de todos os domicílios paulistas, possuindo ou não escravos, eram formados por casais com ou sem filhos, pais ou mães - viúvos, solteiros ou casados - com filhos. Receber parentes próximos ou afastados em suas casas, ou a convivência de vários núcleos familiares em um mesmo teto eram situações excepcionais e temporárias. Anotou ainda, a autora, que, nas pequenas porcentagens de grupos domésticos de famílias extensas e de famílias múltiplas, ao contrário do que se poderia esperar, a maioria dos indivíduos e núcleos familiares que viviam sob a dependência do chefe do domicílio não tinha vínculo de parentesco. Eram insignificantes as porcentagens das pessoas vivendo de favor em casas de familiares, pois preferiam residir, em casos de necessidade ou em situações anormais, agregados em casas de estranhos. Desde que a necessidade fosse superada ou a anormalidade contornada, estes agregados procuravam estabelecer sua residência separada (MARCÍLIO, 2000, cap.5).

Exatamente por essas características, esta obra sempre foi utilizada como contraargumento à vigência da ordem patriarcal no Centro-Sul do Brasil escravista. A própria autora faz referência a isso, argumentando que suas descobertas fazem cair por terra teses prevalecentes na historiografia tradicional,

como a de Ellis Júnior, por exemplo, que pretendia uma predominância patriarcal "onde viviam filhos e netos e até mesmo os ramos bastardos colhidos com a maior isenção de ânimos pelas donas paulistas". $E$ mais, que "elevado era o número de pessoas que formavam a família, quase constituída pelo casal de velhos e 10 ou 12 filhos do primeiro matrimônio, outros tantos do segundo" (MARCÍLIO, 2000, p.99).

Da mesma forma como muitos historiadores dedicados a esse tema, é possível concordar que o domicílio patriarcal, tal como aparece descrito em Oliveira Vianna, Ellis Junior e mesmo Gilberto Freyre, dificilmente pode funcionar como paradigma dos domicílios paulistas daquele período. Porém, o cruzamento dos dados sobre composição domiciliar, produção e posse de terras, e a observação da dinâmica da configuração domiciliar da freguesia de São José dos Pinhais - isto é, suas mudanças no tempo - puderam ao menos sugerir o caráter patriarcal das relações estabelecidas entre homens e mulheres livres.

Se o quadro geral de uma sociedade se expressa no comportamento padrão (no caso, família conjugal/estrutura domiciliar simples), as relações de poder e a hierarquia que a organiza só podem se expressar nos diversos comportamentos. Nesse sentido, o fato de que pelo menos $10 \%$ da população livre de São José dos Pinhais, em 1803, e 4,2\% em 1827 (este, um provável sub-registro) estivesse estabelecida em casa de parentes não-nucleares não parece um comportamento desprezível. Menos desprezível ainda é a observação de que $23 \%$ dos domicílios da freguesia tinham ao menos um parente não-nuclear em 1803 e cerca de $10 \%$ em 1827. Da mesma forma, $5 \%$ da população livre vivendo como agregada em 1782, 5\% em 1803 e 3,7\% em 1827 pode parecer pouco, mas é sociologicamente relevante quando se atenta que $10 \%$ dos fogos de São José tinham agregados em 1782, 18,5\% em 1803 e 12\% em 1827. Ademais, se viver em casa de parente ou agregado em domicílio de estranhos era situação temporária, isso não torna desimportante o fenômeno; ao contrário, revela que era estratégico.

Tudo leva a crer, desse modo, que a diversidade da organização domiciliar é necessariamente um dos componentes explicativos da hierarquia daquela sociedade, e sua dinâmica é especialmente estratégica para a percepção dos esforços de movimentação das pessoas em ambientes aparentemente pouco hierarquizados.

Outro argumento comumente utilizado contra a tese do patriarcalismo é a inferência de Maria Luiza Marcílio (2000, p.98) de que

a própria organização da produção agrícola, fundada em larga escala no sistema de roça de alimentos aberta na mata, não permitia a existência de casas com numerosas pessoas, de famílias extensas ou múltiplas. O precário patrimônio do 
camponês da roça de subsistência, a rusticidade de seu rancho de sapé [...], as sucessivas mudanças de local da roça, todo esse sistema requeria a prevalência de agrupamentos familiares simples.

Este é de fato um quadro bastante fidedigno, porém, não se deve generalizar a idéia de que "as sucessivas mudanças de local da roça" necessariamente implicava mudanças também sucessivas de residência. A estabilidade da população de São José (a maioria dos chefes de domicílio era natural da própria freguesia, ou dos arredores) é indício do que se está propondo aqui. Em muitas regiões a rotatividade das terras de plantio ocorria em um perímetro limitado. Para São José dos Pinhais, um testemunho um pouco tardio, de meados dos anos de 1850, vem referendar esta impressão. Trata-se do relato de um imigrante alemão que, por essa época, se estabeleceu com sua família naquela região, o qual faz referência a "moradores que possuíam outras propriedades, nas vizinhanças, além daquela em que viviam. ${ }^{15}$

Além disso, o cruzamento de dados aqui realizado indica ser possível relativizar a tese da inviabilidade econômica dos domicílios numerosos. Ao menos em São José dos Pinhais, como se viu, o aumento da produtividade, a diversificação da produção, a venda de excedentes no mercado e a incorporação de novas terras relacionavam-se com a capacidade de reunir um maior número de pessoas no domicílio, ainda que poucos tivessem sucesso nessa empreitada.

Talvez não por acaso, as informações sobre composição domiciliar do vilarejo mostraram que, conforme se reduzia a capacidade de comprar escravos, mais a elite escravista se dispunha a incorporar os agregados que, antes, estavam basicamente estabelecidos nos fogos não-escravistas. Somente a atenção à plasticidade dos elementos que sustentavam aquela organização hierárquica permite entender, igualmente, porque tantos dos mais pobres entre aqueles homens de "precário patrimônio" abrigavam parentes não-nucleares e agregados em seus ranchos rústicos.

A professora Marcílio percebeu muito bem tal empenho, quando indica que, na população livre da Capitania de São Paulo, as razões de dependência eram muito baixas, sugerindo utilização intensiva de mão-de-obra infantil e feminina como meios necessários para a sobrevivência dos grupos domésticos. E o costume de se aceitarem agregados foi a maneira encontrada pela sociedade para complementar a diminuta força de trabalho familiar e a estrutura da população livre com baixa razão de masculinidade nas idades adultas, sendo que as famílias com maiores recursos recorriam à importação de escravos (MARCíLIO, 2000, p.105-107).

Octavio lanni, que realizou um estudo extensivo sobre a escravidão no Paraná, embora tenha caracterizado a região a partir do modelo patriarcalista clássico, ${ }^{16}$ não deixou de, ao menos, registrar (embora não tenha ido adiante disso) a natureza mais sutil das relações de poder que ligavam hierarquicamente aqueles homens livres pobres entre si, e que estão expressas na composição domiciliar da região:

Havia uma compulsão econômico-social levando continuamente os brancos à utilização do trabalho escravo, o que tinha diferentes funções, além de ser requisito da definição de status elevado. E quando o nível de renda da unidade não possibilitava a compra de trabalhadores, o branco incorporava agregados, geralmente pardos, com a finalidade de suprir-se de força de trabalho para as atividades que um senhor não deve realizar. Mesmo famílias pobres, que apenas produzem para o próprio sustento apóiamse na força de trabalho de agregados ou mesmo escravos. [...] É desta maneira que os brancos definem-se reciprocamente as

\footnotetext{
${ }^{15}$ Ele menciona, por exemplo, que tiveram como vizinha uma viúva que mantinha uma grande horta em sua propriedade. Certo dia ela os avisou que todos iriam à sua roça de milho para fazer a colheita, e que se durante sua ausência precisassem de couve, bastaria falar com o negro velho que ficaria para cuidar da propriedade, e que os atenderia. Menciona também que um outro vizinho Ihes propôs a venda de uma propriedade que ficava a meia hora de São José, na estrada que seguia para Morretes, constituída por um terreno com uma boa casa, área cercada para plantação e com um tanque com monjolo (STROBEL, 1987, p.63-64).

${ }^{16}$ lanni se utiliza especialmente das obras The brazilian family, de Antonio Cândido, e Casa-grande \& Senzala, de Gilberto Freyre.
} 
posições sociais relativas. É desse modo, quase que exclusivamente, que os brancos de poucos recursos conseguem afirmar-se e firmar-se em determinadas posições da estrutura econômico-social da comunidade (IANNI, 1988, p.74). ${ }^{17}$

No entanto, pode-se concordar quando a professora Maria Luiza Marcílio enfatiza a rusticidade e a precariedade econômica da maior parte da população da região paulista, de modo que o poder patriarcal ali vigente seria sempre um pouco "capenga", permitindo à "arráia miúda" escapar mais facilmente das teias da dependência, num meio como este, no qual mesmo a elite (muito modesta para os padrões da colônia) tinha dificuldade de incorporar terras e homens aos seus domínios.

No entanto, se individualmente a dependência em relação a um parente ou a um estranho podia ser muitas vezes transitória, no conjunto (ou estruturalmente) era mecanismo eficiente na constituição e reprodução da desigualdade no interior do vilarejo, e mesmo no interior de cada domicílio. Por esta razão, o desejo de autonomia, e de se tornar um "pequeno patriarca", ${ }^{18}$ acabava por seduzir mesmo os mais modestos, posto que sua concretização seria fonte de distinção social e, portanto, de mobilidade ascendente.

Tal quadro guarda certo nexo com a lógica da organização domiciliar de diferentes regiões da Europa do Antigo Regime. Em "As mil e uma famílias da Europa", Burguière e Lebrun (1998, p.31-32), com base nos resultados de trabalhos de inúmeros pesquisadores, afirmam que a dimensão das famílias no Antigo Regime era mais um índice de poder social do que de vitalidade demográfica. Embora a citação seja longa, vale a pena transcrevêla quase na íntegra.

É a riqueza que permite às classes superiores manter em suas casas um grande número de criados e albergar parentes isolados. Esta superioridade observa-se numericamente nos aglomerados onde reina uma certa segregação social. Em Györ (Hungria), no século XVIII, as famílias são nitidamente maiores no centro da cidade onde reside a burguesia rica, e em Viena no aristocrático bairro de Herrengassen.

Em compensação, quando uma casa nobre ou burguesa se separa do conjunto e afirma a sua superioridade, as estatísticas deixam de a localizar. É o caso da Inglaterra, onde a gentry, ao contrário dos outros nobres europeus, habita de preferência no campo. Das médias obtidas a partir das "cem aldeias inglesas" temos uma impressão de grande uniformidade: um povo de famílias reduzidas. Ora era exactamente a impressão oposta que os camponeses tinham da presença imperiosa, em cada aldeia inglesa (ou pelo menos quatro aldeias em cada cinco), do castelo senhorial.

Em Goodnestone next Wingham, o vigário recenseia em 1676 uma das três famílias de fidalgos, a do nobre Hales, e conta 23 pessoas, entre as quais 15 criados. Como estes criados, muito jovens em relação ao agregado, são quase todos procedentes da paróquia, podemos dizer que uma família em cada cinco, em Goodnestone, está ao serviço do nobre Hales. Este modesto fidalgo - nem sequer é proprietário - ilustra à sua escala a dimensão ostentatória da família aristocrática. A abundante criadagem, assim como o facto de manter sob o seu tecto uma parte dos seus parentes, não tem a ver com o aspecto económico, mas sim com uma obrigação social. Consumir mão-de-obra até ser excessiva é uma prova de poder e de generosidade em relação às famílias que podem empregar os seus filhos.

Fora do círculo das elites, a dimensão das famílias tem a ver com a situação económica, na base da capacidade de produzir, não de gastar. Na Europa ocidental, as grandes famílias camponesas (as dos yeomen em Inglaterra ou dos "lavradores" em França) acumulam superioridade económica e poder social. Mas na Europa Central e Oriental, o tamanho das famílias já não coincide necessariamente com a posição social. Em Villgraten, pequena aldeia dos Alpes austríacos cujos habitantes se dedicam à criação de gado bovino (grande consumidor de mão-de-obra), a dimensão das famílias em 1781 varia exactamente com a das manadas. Em Nagykovacsi, aldeia húngara perto de Buda, são servos quem

\footnotetext{
${ }^{17}$ Uma visão um pouco diferente está em Machado (2006, cap. 4), em que se realiza uma discussão sobre práticas patriarcalistas entre libertos e livres de cor.

${ }^{18}$ Expressão cunhada por Lima (1997).
} 
têm as maiores famílias (...) e a população livre as mais pequenas (...). Nesta região, os camponeses proprietários submetidos à servidão são muitas vezes os mais ricos.

(...) Na Europa moderna, a hipertrofia do grupo doméstico não é uma característica da servidão mas de todos os sistemas de exploração em que a quantidade de mãode-obra investida regula, simultaneamente, o lucro do rendeiro e o dinheiro retirado pelo proprietário.

\section{Referências bibliográficas}

ANDREAZZA, M. Olhares para a ordem social na freguesia de Santo Antônio da Lapa 1763-1798. In: XIII ENCONTRO NACIONAL DE ESTUDOS POPULACIONAIS. Anais... Ouro Preto: ABEP, 2002 (Disponível em CDROM).

BACELLAR, C. A. P. Agregados em casa, agregados na roça: uma discussão. In: SILVA. M. B. N. da (Org.). Sexualidade, família e religião na colonização do Brasil. Lisboa: Livros Horizonte, 2001, p. 187-199.

BARICKMAN, B. J. Um contraponto baiano. Açúcar, fumo, mandioca e escravidão no Recôncavo baiano, 1780-1860. Rio de Janeiro: Civilização Brasileira, 2003.

BARTH, F. O guru, o iniciador e outras variações antropológicas. Rio de Janeiro: Contracapa, 2000.

BRÜGGER, S.M.J. Minas patriarcal: família e sociedade em São João Del Rei (séculos XVIII-XIX). Tese de doutorado. Niterói: UFF, 2002.

BURGUIÈRE, A.; LEBRUN, F. As mil e uma famílias da Europa. In: BURGUIÈRE, A. et al. (Dir.). História da família. O choque das modernidades: Ásia, África, América, Europa. Lisboa: Terramar, v.3, 1998, p. 3132.

CORRÊA, M. Repensando a família patriarcal brasileira. In: ARANTES, A. et al. Colcha de retalhos: estudos sobre a família no Brasil. 3. ed. Campinas: Edit. Unicamp, 1994.

COSTA, I. del N. Vila Rica: população (17191820). São Paulo: IPE/USP, 1979.
Se no Antigo Regime europeu uma mesma prática ajudava a produzir diferentes relações políticas e específicas conformações sociais, isso também deveria ocorrer no Brasil escravista. Assim, a despeito da aparência de uniformidade social e de organização familiar reduzida, a ordem patriarcal e escravista parecia vigir nesse ambiente de homens pouco poderosos e de população escrava escassa.

COSTA, I. del N. e GUTIÉRREZ, H. Paraná: mapas de habitantes, 1798-1830. São Paulo: IPE, 1985.

CUNHA, M. C. da. Negros estrangeiros: os escravos libertos e sua volta à África. São Paulo: Brasiliense, 1985.

FERREIRA, R. G. Pardos: trabalho, família, aliança e mobilidade social. Porto Feliz, São Paulo, c. 1798 - c. 1850 . Tese de doutorado. Rio de Janeiro: PPGHIS/UFRJ, 2005.

FIGUEIREDO, L. R. A. Barrocas famílias: vida familiar em Minas Gerais no século XVIII. São Paulo: Estudos Históricos/Hucitec, 1997.

GUTIÉRREZ, H. A estrutura fundiária no Paraná antes da imigração. Estudos de História, Franca, SP, v.8, n.2, p. 209-231, 2001.

IANNI, O. As metamorfoses do escravo. 2.ed. São Paulo: Hucitec/Curitiba: Scientia et Labor, 1988.

KUSNESOF, E. The role of female-headed household in brazilian modernization: 1765-1836. Journal of Social History, 13(4), p.589-612, Summer, 1980.

LIMA, C. A. M. Pequenos patriarcas: pequena produção e comércio miúdo, domicílio e aliança na cidade do Rio de Janeiro (1786-1844). Tese de doutorado. Rio de Janeiro: PPGHIS/UFRJ, 1997.

LONDOÑO, F. T. A outra família: concubinato, igreja e escândalo na Colônia. São Paulo: Ed. Loyola, 1999. 
MACHADO, C. A trama das vontades. Negros, pardos e negros na produção da hierarquia social (São José dos Pinhais - PR, passagem do XVIII para o XIX. Tese de doutorado. Rio de Janeiro: IFCS/UFRJ, 2006.

MARCÍLIO, M. L. Crescimento demográfico e evolução agrária paulista. 17001836. São Paulo: Hucitec, 2000.

PENA, E. S. O jogo da face: a astúcia escrava frente aos senhores e à lei na Curitiba provinciana. Curitiba: Aos Quatro Ventos, 1999.

SAMARA, E. de M. O papel do agregado na região de Itu. 1780 a 1830. São Paulo: Museu Paulista, v.6, 1977 (Coleção Museu Paulista, série História).
A família brasileira. São Paulo: Editora Brasiliense, 1984.

(Org). A família no Brasil: história e historiografia. São Paulo: Cedhal-USP, 1998 (Série Fontes de Pesquisa).

SILVA, M. B. N. da. Sistema de casamento no Brasil Colonial. São Paulo: T.A .Queiroz/ Edusp, 1984.

STROBEL, G. H. Relatos de um pioneiro da imigração alemã. Estante Paranista, 27, Curitiba: IHGEPr, 1987.

VAINFAS, R. Trópico dos pecados. Moral, sexualidade e Inquisição no Brasil. RJ: Campus, 1989.

\begin{abstract}
The possible patriarchalism: power relations in a former slave region in Brazil where family labor was the rule

In this article I have attempted to show indications of a peculiar configuration of patriarchalism in certain food-producing regions. In these regions family labor was the rule and, from the demographic point of view, slavery was inexpressive. The locus of the study is "Freguesia de São José dos Pinhais" (State of Paraná) in the 18th and 19th centuries, and the dynamic of the social relations there is analyzed through data on household composition, production and landholding.
\end{abstract}

Key words: Patriarchalism. Dependence. Slavery.

Recebido para publicação em 09/11/2005.

Aceito para publicação em 17/03/2006. 